\title{
Deur die wasmasjienvenster na binne en na buite
}

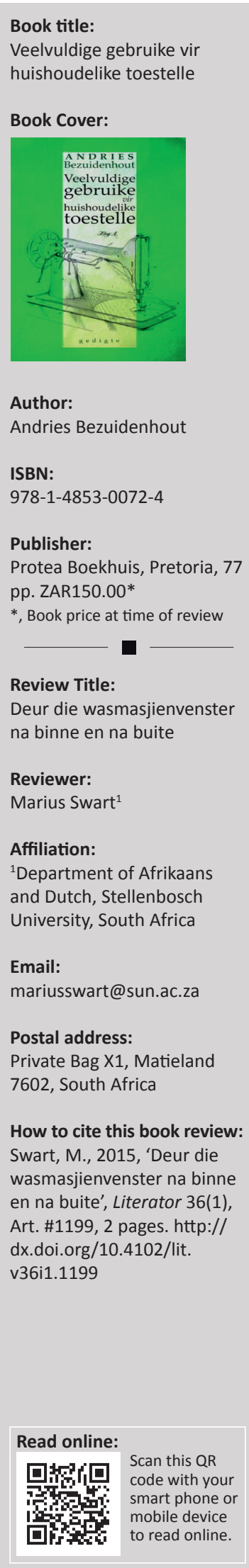

Andries Bezuidenhout se tweede bundel gee tegelykertyd blyke van die skrywer se veelvlakkige kunstenaarskap en sy nering as sosioloog. Tesame met patentsketse (ongelukkig baie klein gedruk) waarop deur die skrywer bygeteken is, tref die leser in hierdie bundel verwysings na verskeie ander kunsvorme aan, waaronder die skilderkuns, die digkuns, musiek en dies meer; verwysings wat uitgebrei word in versreëls soos 'ons die arme geeste van skepping / ons die gode' ('Dagdroom'). Hierdie verwysings is deel van 'n opmerklike intertekstuele gesprek met sowel die werk van Afrikaanse skrywers (Gert Vlok Nel, Sheila Cussons en andere), as met advertensies, lirieke, die wêreldletterkunde, sosiologiese vakliteratuur en filosofiese werke (soos telkens aangedui in die motto's by sommige gedigte en in die omvattende lys 'Bestanddele' agter in die bundel). Eweneens figureer die maatskaplike problematiek en politieke geskiedenis van die land in heelparty gedigte, hetsy eksplisiet ('ons is die ratte, die rusperwiele van stootskrapers /wat mure moes platstoot' in 'Onderdele') of meer verhul (in gedigte soos 'Welverdiend', die roerende 'Aansoek om betrekking' met sy ontnugterende slot, asook die ritmiese 'Ritrympie').

Die eerste gedig, voorsien van 'n motto uit McCarthy se The road, open die bundel op ' $n$ bepaald apokaliptiese noot wat ook siklies verband hou met die laaste gedig waarin 'n terrein naby rotsgravures besoek word. Die slotreël van die slotgedig bevestig hierdie indruk: 'Eendag sal lawa nogmaals boontoe beur / en alles wéér metaformeer.'

Tussen hierdie punte tref die leser heelparty verwysings aan na veral die sosio-politiese realiteit in Suid-Afrika. Daar is die middeljarige wit weduwee wat werk soek as huishulp in 'Aansoek om betrekking', liefdelose huwelike, egskeidings, middelmisbruik, die groepsgebiede en afwesige pa's in gedigte soos 'Die jaar toe pa die skottelgoedwasser gewen het'. Verder ook 'Draalgedig vir'n derde kind', kinderarbeid, korrupsie en die (letterlik) oorvrete staatsdiens in 'Ritrympie'; 'n beskouing van die selektiewe herskrywing van die geskiedenis in 'n gedig soos 'Wat in die kombuis gebeur', asook die ontvolking van die platteland in byvoorbeeld 'Welverdiend', 'Church Going' en 'Perron'.

Die ekologiese figureer eweneens sterk in die bundel, veral in gedigte soos 'Hoe kokerbome breek', 'Verstrooide aarde' wat 'n aanklag vorm teen kommersiële voedselverbouing, in 'Road kill' en 'Ritrympie', asook in 'Welverdiend' met die verwysings na 'skroot' en 'uitgemynde skagte'. Hierdie tema sit ook onder die oppervlak van heelparty gedigte wat daarbenewens oor reise en besoeke gaan, byvoorbeeld 'Wegraping', 'n indrukwekkende gedig met 'n sterk slot.

Die bundel bevat heelwat liefdesverse waarvan ' $n$ paar besonder sterk is. In 'Die handpalmleser van Swakopmund' word verlangend op 'n ou spoor teruggeloop. Verlies word aangeroer in 'Koelkas', 'n gedig wat heelwat potensiaal vir verdere omdigting het, maar nog nie volledig ontwikkel is nie. Die wyse waarop verliefdheid die alledaagse laat vervaag, vertoon sterk in die heerlike 'Alles wat die lug indamp stol en word solied' (waar die leser tog struikel oor die afwesigheid van die komma in die titel en die onverwagse dubbele spasies tussen sommige woorde, hoewel laasgenoemde struikelblok moontlik doelbewus ingebou is). In 'Rent-a-husband' spot die spreker met homself deur sy manlike bedrewenheid in en om die huis verrassend beide te bevestig en te ondermyn.

Die reise wat deur die spreker onderneem word, word telkens afgewissel met 'n terugkeer na die veilige ruimte van die kombuis - dieselfde kombuis waaruit nogeens waargeneem en nagedink word, waarbinne gedroom word, en waarbinne die meeste huishoudelike toestelle natuurlik staan en bestaan. Hier is dit tyd vir 'klop en karring' (bl. 17), hier word geëet, hier word die 'watersuistoonhoogte / deur pype soggens en saans' gehoor (bl. 69). Hier gaan dit oor siklusse soos 'verdamp en kondenseer' (bl. 66). Die warm, geborge ruimte van die eie kombuis en die inwonende toestelle word vernuftig afgespeel teen elemente soos die 'dun koue straaltjie' water in die badkamer van 'n 'wankelhopige hotelkamer' (bl. 61). Die kombuis is 
die ruimte waar die spreker se moeder enersyds 'uit boeke onthaal' het (bl. 30) en waar die geskiedenis andersyds 'opgekook' word (bl. 27). Dit is ook soms die ruimte waar dinge verkeerd loop - hier 'val brode plat' (bl. 19), en hier heers soms 'n 'stomheidseed' (bl. 9) tussen saamgebonde toestelle.

Heelwat verwysings na wasmasjiene, hetsy naamlose wasserymodelle of spesifiek die Defy Automaid, as handelsnaam én as ironiserende grap, kom veral in die sterker verse voor, en wasmasjiene is ook die sentrale element in die uitmuntende gedig 'Wasmasjien'. In hierdie gedig, eintlik 'n stel van twee gedigte wat aansienlik verskil in toonaard, kom die digter se bedrewenheid deeglik na vore. Hier word die alledaagse en die poëtiese naatloos verenig, en die kosmiese vervleg met die bykans banale om 'n hoogtepunt in die bundel te vorm.
Die bundel het plek-plek klein talige en taalkundige oneffenhede, soos die minder gebruiklike spelling van 'orraait' as 'oraait' (bl. 61), asook leestekens wat soms met vrug aangewend kon word waar hulle tans nie staan nie, en samestellings wat die Afrikaanse lesersoog eers laat stop en herlees. Daar is gedigte wat sterker kan staan met 'n mate van uitbreiding of verdere omdigting, byvoorbeeld 'Skottelgoed skilder'. Soms eindig 'n gedig nogal abrup, soos in die geval van 'Dagdroom', en in enkele gevalle blyk die gedig gewoon nog te verhul vir hierdie leser, soos in die geval van 'Palomar Place, Observatory'.

Hier is egter 'n vaardige digter aan die werk wat 'n eiesoortige blik bied op die maatskaplike problematiek in die land en, uiteraard, op die mens en sy bestaan hier tussen die dinge wat hy maak, en wat hom toenemend maak wie en wat hy is. 